\section{Cable of protest}

One hundred and six Fellows of the Royal Society, including four Nobel Prize Winners, (Sir Nevill Mott, Sir Max Perutz, Sir George Porter, and Dr Fred Sanger) have sent the following telegram to the Soviet Delegation to the Madrid Review Conference.

"The arrest of Dr Brailovskii is a cause of great concern which can only harm further scientific exchange between our countries."

Viktor Brailovskii, arrested on 13 November, the day after the opening of the Madrid Conference, is thought to be facing charges under Article 191/1 of the Soviet Penal Code: Disseminating information known to be false and detrimental to the Soviet Union and socialist system. His detention, however, seems to be linked with his activity as host to the Sunday seminars for Jewish refusnik scientists in Moscow. Last week, his wife was warned by the security authorities not to try to go ahead with the seminar. When, on Sunday, she attempted to hold the seminar, intending participants were prevented by the police from entering the apartment.

In Washington last Sunday, the Committee of Concerned Scientists organized a seminar on the style of the Moscow seminar. A paper was read by $\mathrm{Dr}$ Maxine Singer who earlier this year was refused a visa to visit Moscow, where she had intended to visit the Brailovskii seminar. Several of the participants had read papers at the Brailovskii seminar during professional visits to Moscow. It is hoped to hold such seminars every Sunday in various US academic centres.

An international delegation of scientists, led by the French Nobel Laureate Andre Lwoff, who is a corresponding member of the Soviet Academy of Medical Sciences, is seeking a meeting with Ilichev, head of the Soviet delegation in Madrid, to discuss the Brailovskii case.

Vera Rich

managed developments, ranging. from recreation to heavy transport, with canal links through the Soviet Union and East Germany. Such a major project cannot, of course, be simply abandoned, but as the press spokesman for the programme recently pointed out, it is a complex plan, the implementation of one part does not necessarily depend on that of another, and, in any case, the announced completion deadline of the year 2000 had rather "symbolic" significance. Nevertheless, he said, the country simply cannot afford not to implement some parts of the scheme as soon as possible - the anti-pollution and water-storage proposals which will be vital in the next few years if the country's agriculture and industry are to recover.

A similar stance was adopted recently in the Sejm (Parliament) by Deputy Zbigniew Kledecki. Speaking on the pollution of the
Krakow area by the Nowa Huta steel mills and the Skawina aluminium plant, he stated that the cost of installing modern, non-polluting equipment would be 120 million zloty ( $£ 2$ million) at Nowa Huta and 7,500 million zloty ( $£ 125$ million) at Skawina. Nevertheless, he said, in view of the grave pollution hazards and the "critical attitude of community scientists and journalists in Krakow", preparatory work on modernizing the plants would begin next year.

Important as such major investments still may be, the most immediate investment problem is that of agriculture. Recent pledges by the Minister of Agriculture, Leon Klonica, include an increase in the production of plant protection chemicals, and fertilizers, investments in land-improvement, development of an intermediate technology suitable for small farms, changes in the supply and pricing system to aid the private farmer, and a relaxation of central arbitrary planning in agriculture. These last points, which are a considerable reversal of recent policy, have been welcomed by the farmers with cautious approval.

Vera Rich

\section{Brazilian universities}

\section{No cash ahead}

\section{Sao Paulo, November}

Inflation and a lack of sympathy from the state government have forced the University of São Paulo (USP), Brazil's oldest university and one of its best, into a serious crisis. But the crisis is not confined to São Paulo. All government-supported universities face difficulties over dwindling budgets. Academics throughout Brazil have been protesting about the lack of resources by holding a series of one or twoday stoppages, the latest at the beginning of this month.

The academics' complaint is that the state and federal governments have made the universities take an unfair share of public expenditure cuts and have thus neglected the country's long-term future in the panic to service Brazil's massive foreign debt and oil import bill. This results in the universities having virtually no money for new building and very little for buying and maintaining equipment.

The most serious complaint, however, is the effect of inflation on academic salaries, which have recently been increasing at only about half the rate of inflation and which are corrected only once a year. (The academics are asking for termly readjustment.) The lack of money available for salaries has meant that some academics have to turn to part-time and piecework teaching. Many academics can get contracts for only 20 hours a week and have to eke out a living by other means. But even those with 40-hour contracts are finding it necessary to look for ways of topping up their incomes.

Salary problems seem to vary from one university to another and depend on how individual funds are administered. Some federal universities, called fundações, are allowed to keep their own trust funds which are being used to top up salaries, but others, the autarquias, are strictly limited to paying agreed government salaries only. For those in the humanities in the autarquias, the outlook is bleak, but for scientists there is a chance of extra support from the national research councils, which have recently started to top up researchers' salaries as well as making research grants. The budgets of the research councils have not, however, stretched to helping every scientist worthy of support.

The number of applications made to the main research council, the Conselho Nacional de Desenvolvimento Cientifico e Tecnologico (CNPq), for grants to supplement salaries increased dramatically in 1980. The CNPq estimates that it is now supplementing about 2,200 scientists' salaries and that its sister organizations may be supplementing as many as 3,000 . Most notable, says the $\mathrm{CNPq}$, is the large increase in applications from the University of São Paulo.

For federal universities, the $\mathrm{CNPq}$ is confident that the problem is only temporary and that the salaries problem will be alleviated by the beginning of the next academic year in March. The University of São Paulo, however, cannot necessarily expect such a reprieve. Its finances are controlled by the government of the state of Sao Paulo which allocates the budget annually - the most serious deterioration in the university's finances has occurred over the past few years, since a change in the state government.

If São Paulo has been hit more severely than most of the federal universities, it may be - according to one administrator - that the university had more to lose. But many academics and newspaper reports blame the crisis on the governor of Sao Paulo state, Paulo Maluf, who is keener on oil exploration projects than on the university.

The university's teachers' association says that its share of the state budget decreased from 3 per cent in 1975 to 1.89 per cent in 1980, and that the share taken by higher education generally decreased from 5.1 per cent to 3.3 per cent over the same period. The same figures put the average salary of a full-time professor at about 80,000 cruzeiros a month ( $£ 6,000$ a year), less than half of its maximum real value in the past decade. But budgets are not the only problem afflicting Brazilian universities. Their rapid expansion from 500,000 students in 1968 to 1.5 million now has led to unwieldy bureaucracies which changes of government have only aggravated. At São Paulo, the seat of university unrest in 1968, academics say that even relatively small items of expenditure have to be approved by the rector, who in turn has to argue for funds with the state government.

Judy Redfearn 